\title{
The nature of the carbon source as a modulator of the response of bacteria to biologically active compounds (for example, colchicine and protatranes) \\ Markova Yu.A. ${ }^{1}$, Belovezhets L.A. ${ }^{2}$, Tretyakova M.S. ${ }^{1}$, Cheremnykh A.M. ${ }^{1}$, Levchuk A.A. ${ }^{2}$ \\ ${ }^{1}$ Siberian Institute of Plant Physiology and Biochemistry, Irkutsk, Russia; ${ }^{2}$ A.E. Favorsky Irkutsk Institute of Chemistry SB RAS, Irkutsk, Russia \\ E-mail: juliam06@mail.ru
}

Key message. When assessing the impact of biological active compounds (colchicine and protatranes) on Rhodococcus erythropolis against the background of various carbon sources, an unusual effect of low concentrations of colchicine was revealed, that expressed in sharp stimulation of bacterial metabolism.

Keywords: Rhodococcus erythropolis, colchicine, protatranes, carbon sources

The resistance of bacteria to the action of biologically active compounds (BAC) is due, on the one hand, to their genetic characteristic and, on the other hand, to environmental conditions. Depending on the carbon source in the bacterial cell, the redistribution of metabolic pathways occurs, which leads to a change in its physiological status, thereby modulating resistance $(1,2)$. This phenomenon is actively studied in the interaction of bacteria with antibiotics, but it also occurs in the case of other BAC. We found an unusual effect of low concentration of colchicine on Rhodococcus, expressed in a sharp stimulation of bacterial metabolism. In microorganisms formed in an environment with glucose, the participation of colchicine stimulates catabolic processes, which is expresses in the activation of respiration without significant bio-stimulation and influence on biofilm formation. With growth on inositol and naphthalene, short-term activation of respiration occurs, probably due to selfdestruction of cells, therefore, an oxidative explosion was observed in the first hours of cultivation. However, with growth on inositol, biofilm formation increases, therefore, most of the cells decrease metabolic activity. Whereas when using naphthalene as a substrate, colchicine does not affect the formation of biofilms. At the same time, significant stimulation of the growth rate may be associated with accelerated destruction of naphthalene by Rhodococcus in the presence of colchicine. The study was supported by a grant from Russian Foundation for Basic Research, project № 20-016-00114 A and the integration program «Fundamental Research and Breakthrough Technologies as Basis for the Development of the Baikal Region and its Interregional Relations».

\section{Природа источника углерода как модулятор ответа бактерий на биологически активные соединения (на примере колхицина и протатранов)

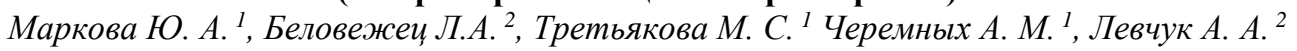 ${ }^{1}$ СИФИБР СО РАН, Иркутск, Россия; ${ }^{2}$ ИрИХ СО РАН, Иркутск, Россия}

\begin{abstract}
Аннотация. При оценке влияния БАС (колхицина и протатранов) на Rhodococcus erythropolis на фоне различных источников углерода, обнаружено необычное воздействие низких конщентраций колхищина, выражающееся в резкой стимуляции метаболизма бактерии.
\end{abstract}

Ключевые слова: Rhodococcus erythropolis, колхицин, протатраны, источник углерода

Устойчивость бактерий к действию биологически активных соединений (БАС) обусловлена с одной стороны их генетическими особенностями, а с другой условиями внешней среды. В зависимости от источника углерода в бактериальной клетке происходит перераспределение метаболических потоков, что приводит к изменению ее физиологического статуса, тем самым модулируя резистентность $(1,2)$. Это явление активно изучается при взаимодействии бактерий с антибиотиками, однако оно имеет место и в случае использования других БАС. Нами обнаружено необычное воздействие низких концентраций колхицина на Rhodococcus, выражающееся в резкой стимуляции метаболизма бактерии. У микроорганизмов, культивируемых в среде с глюкозой, внесение колхицина стимулирует катаболические процессы, что выражается в активации дыхания без значимого прироста биомассы и влияния на биопленкообразование. При росте на инозите и нафталине происходит кратковременная активация дыхания, вероятно за счет саморазрушения клеток, поэтому окислительный взрыв наблюдался в первые часы культивирования. Однако, при росте на инозите биопленкообразование возрастает, следовательно, большая часть клеток снижает метаболическую активность. Тогда как при использовании в качестве субстрата нафталине, колхицин не влияет на образование биопленок. В то же время значимая стимуляция скорости роста может быть связана с ускоренной деструкцией нафталина родококком в присутствии колхицина. Исследование поддержано грантом РФФИ, проект № 20-016-00114 А и интеграционной программой «Фундаментальные исследования и прорывные технологии как основа опережающего развития Байкальского региона и его межрегиональных связей».

1. Su Y. et al. Pyruvate cycle increases aminoglycoside efficacy and provides respiratory energy in bacteria //Proceedings of the National Academy of Sciences. - 2018. - T. 115. - №. 7. - C. E1578-E1587.

2. Meylan S. et al. Carbon sources tune antibiotic susceptibility in Pseudomonas aeruginosa via tricarboxylic acid cycle control //Cell chemical biology. - 2017. - T. 24. - №. 2. - C. 195-206. 